\title{
The utopian dimension in the philosophy of social betterment in Adam Smith
}

A dimensão utópica na filosofia do melhoramento social em Adam Smith

Maria Pia Paganelli (1)

(1) Trinity University, USA

\begin{abstract}
Adam Smith does not focus on the creation of an ideal world, but on the understanding that societal changes for the better are an unintentional product of commerce. Furthermore, as if to highlight the concreteness of these changes, he sees population growth as the way to measure this betterment of society.
\end{abstract}

\section{Keywords}

Adam Smith, utopia, social betterment, improvement, growth.

JEL Codes B12, J1, O20.

\section{Resumo}

Adam Smith não se concentra na criação de um mundo ideal, mas no entendimento de que mudanças sociais para melhor são um produto não intencional do comércio. Além disso, como que para destacar a concretude dessas mudanças, ele vê o crescimento populacional como a forma de medir essa melhoria da sociedade.

\section{Palavras-chave}

Adam Smith, utopia, melhoramento social, methoria, crescimento.

Códigos JEL B12,J1, O20. 


\section{Introduction}

Can we make a better society? Should we? How do we know if we have made it better? Adam Smith, in line with some of his contemporaries Eighteenth-century Scottish enlightenment thinkers such as David Hume, John Millar and Adam Ferguson, answers these questions differently from many of his European contemporaries, predecessors, and successors. In contrast to them, Smith lacks a utopian dimension to his philosophy of how to make society better. Instead he focuses on the reality of social change and seeks ways to measure how a society can be considered as getting better. For Smith, social betterment is generally the result of a combination of luck and the unintended consequences of human interactions, which can be measured by changes in the rate of growth of population.

After defining social betterment, I show how for Smith this betterment is the unintended and not inevitable result of a silent commercial revolution, rather than of a rationalistic utopian design. A discussion of how Smith sees population growth as a way to measure this betterment precedes some concluding remarks.

I use the term social 'betterment' to highlight that there are changes in societies that do not fall in the categories of improvement, progress, and development. Improvement generally refers to micro-level local improvements; progress generally refers to macro-level designed utopic progress; and development to the inevitable and sort of mechanical, even if at times not linear, stadial development of society.

Betterment is not a term Smith uses. Smith uses the expression "bettering our condition", though, to refer to the innate drive that motivates many of our actions. But while our desire to better our condition is a force that works at the individual level, and that can lead us to plan our conduct to achieve our wished-for results, the idea I would like to express with "social betterment" remains at the aggregate level, so society as a whole becomes better off, not just single individuals in it. Furthermore, this social betterment is not something we can explicitly plan to achieve. And while we can see if an individual bettered their condition by looking at his amount of wealth, we can see if a society achieved some betterment by looking at its population growth.

The choice of the term, thus, even if potentially anachronistically, helps us see the different levels of social changes that can lead to a better human 
condition. I use 'betterment' to differentiate between individual rationally designed micro improvements, rationally planned utopic ideas of progress, and human agency-free deterministic macro developments.

Micro-level improvements characterized the Scottish Enlightenment as an "age of improvements." Social betterment, in the sense of macro-level change for the better, can and does happen, but it is generally the result of a combination of luck and the unintended consequences of human interactions, which can be measured by changes in population growth rates. It is in no way an inevitable step toward development. Neither would it be a rationally planned designed progress. Furthermore, understanding the human condition and the limits of what humans can achieve is not so much a tool for bettering society as it is a way to avoid or contain society's deterioration caused by the hubris of utopian dreams. Social betterment thus simply implies the more humble and realistic ability of a society to increase its population growth rate, in terms of decreased child mortality, increased life expectancy, and improved standards of living. And Smith, rather than focusing on describing ideal societies, focused on measuring changes in real ones.

I therefore suggest that the current literature on the Scottish Enlightenment, which focuses on the idea of it as an age of improvement or as presenting some form of preset stages of development, needs to recognize a distinction between micro-level local improvements and a more general non-rationally constructed and non-deterministic social level notion of betterment. And that, moreover, the social level notion of betterment is linked to the idea of using population growth as a measure of this betterment.

\section{2 "Betterment" rather than improvement, progress, or development}

The Scottish Enlightenment is often referred to as the "age of improvement." Christopher Berry (2013, p. 1) seminally defines it as characterized by its "deliberate intent to 'improve"" (Phillipson 1970; Berry 1997). Yet this is not, and should not be considered, an age of utopic progress. Improvement implies an understanding of reality, an increase in knowledge, which allows us to be better off, given our constraints. Utopic social progress instead implies a design of an ideal, independent of constraints. 
Improvements are thus the result of our better knowledge of reality. This same knowledge of reality leads us to understand the limits of human abilities and to the view that redesigning a "system," a whole new society, is the wrong way to approach social change. Understanding what we can and what we cannot do would allow us to avoid the inevitable disasters of utopic hubris. The knowledge we come to understand is also that general macro-level social betterments are not the result of human plans (Smith 2006, p. 165-166), like the micro-level improvements. And so should not be confused with them. Neither are they the inevitable results of a deterministic development path. Furthermore, the macro-level social betterments can be measured by counting the increasing or decreasing number of people a society is able to sustain.

The concept of improvement in $18^{\text {th }}$ century Scotland provides a justification for experimentation and change. But these are all individual, local, changes, not global ones. Even when we think of their interest in the relationship between men and the environment, how man can influence the environment especially in the case of agriculture, we are still not dealing with attempt to redesign nature according to some ideal standards.

While it is true that "the Scottish Improvers set out to improve Scotland literally "from the ground up" (Bonnyman 2014, p. 5), and to do this, they engaged in a large variety of experiments with an equally large variety of success rates; it is also true that their aim was simply to understand how nature worked and gradually improve knowledge of agriculture. The introduction of spade husbandry and potato cultivation, as well as sheep farming, were successful experiments dating to this time. The introduction of Chinese tea in the Highlands of Scotland was a failed attempt to improve, which eventually led to the introduction of Chinese tea cultivation in India (Jonsson 2013). The many local, micro, improvement attempts, based on the then-current understanding of the world were not grand ideal schemes to redesign the entire society and humankind.

Similarly, Adam Smith ([1776] 1981) believes that banks and bank credit, and free banking in particular, are successful instruments of improvement (WN II.ii). The economic boom of $18^{\text {th }}$ century Scotland was due in part to the innovation of banking (WN II.ii.41, p. 297). The system was not perfect, nor could it be made perfect, but it could be improved. For Smith, the improvement would come from legal restrictions on interest rates (WN II.iv.13-17, pp. 356-359), on small denomination notes 
(WN II.ii.89-94, pp.322-324), and on the ability of banks to suspend convertibility (WN II.ii.98, pp. 325-326). Similarly, for David Hume improvement would come from a reform of the banking system so that it would eventually resemble the one in Amsterdam (Hume [1752] 1985, pp. 284285; see also Paganelli 2014; Dimand 2013). These were suggestions for simple reforms of the existing institutions, not designs for an ideal society inhabited by a redesigned ideal people. They are concrete and clear suggestions for some specific path to take to try to improve a specific micro aspect of society. They are not plans of institutional redesign following a rational design such as in Condorcet (Lukes and Urbinati 2012), or Jeremy Bentham (Schofield and Harris 1999).

Most utopian ideas of progress, on the other hand, do not offer a concrete path to reach utopia. We are seldom given directions to go nowhere. It may not be by accident that utopia is generally described second handedly. It is a report of someone who met someone else who visited utopia. And the way to utopia is more often than not randomly stumbled upon (Davis 2008).

The French Revolution seems to be a watershed in utopian thinking with the idea of utopia moving from literary fantasy to plan for revolutionary transformation of society (Claeys 1994, p. xxvi). It seems that Smith misses this shift to utopian politics. The French Revolution may be one of the expressions of a faith in the construct of Utopia here and now: we create new goods and new technologies; we develop sciences and apply them to everyday life; we rationalize knowledge, making it more fruitful, so we can modify our environment, control and direct the destiny of humankind toward a better world, improving on the imperfections of the existing world and creating a new and better one (Fest 1992).

Not for Adam Smith. He is aware that ideally perfect rational societies may be appealing in theory, but they are not livable in practice (Claeys 1994). Smith ([1762]1985, i.96-116, p. 40-47) knows Johnathan Swift and his Gulliver's Travels (Swift [1723] 2005) as he positively comments on Swift's writing style. Swift warns us, even before the French Revolution, of this ideal impossibility: Gulliver encounters the Houyhnhnms, naturally virtuous creatures who cultivate reason and are governed by it so that all aspects of their society are organized according to logical patterns. Yet, in "a society which [Gulliver] feels to be truly ideal, [...] he is not fit to live there" (Houston 2007, p. 433). Gulliver also travels through ideal and 
perfect societies which, despite their perfection, seem to fail. Leaving religious interpretations aside, Lilliput seems to decline both "because of the 'degenerate nature of man', no institution can guarantee good government or moral virtue" and because the Lilliputians "did not understand their own degenerate nature" (Radner 1992, pp. 53-54). Swift seems to criticize the concept that ideal perfection of institutions may lead society to progress, claiming that even if we had perfect institutions, 'the degenerate nature of man' will corrupt them.

Aware of possible difficulties in implementing utopian idealism, utopias started including accounts of revolutions and violent establishments of new regimes (Claeys 1994). Violence becomes an acceptable option, if all else fails (Popper 1989, p. 357; Berlin 1991, p. 15; see also Smith 2005, p. 221).

While French surrealism eventually will present itself as an alternative to extreme forms of rationalistic utopias and as attempts to "free ourselves from the tyranny of rationalism" (Gardiner 1995, p. 95), in Eighteenth-century Scotland, writers such as Adam Smith distance themselves from this utopian approach preferring a more realistic description and prescription of social betterment instead. In Scotland, as Craig Smith (2005) documented, there may have been a well-grounded reluctance to adopt utopic ideals because, among other things, of the country's exposure to Reformationera attempts to set up a perfect theocracy. The alternative more realistic notion that social betterment may be achieved by the acceptance of the imperfection of human nature and the working of history, with its accidents and unguided (and not necessarily deterministic) evolution, and not by redesigning society or human beings, became dominant.

David Hume in his History of England (Hume [1762] 1985), and later William Paley (Paley [1785] 2000, p. 328), in describing the British constitution, gives us a sense of it:

"The constitution of England, like that of most countries of Europe, hath grown out of occasion and emergency; from the fluctuating policy of different ages; from the contentions, successes, interests, and opportunities, of different orders and parties of men in the community. It resembles one of those old mansions, which, instead of being built all at once, after a regular plan, and according to the rules of architecture at present established, has been reared in different ages of the art, has been altered from time to time, and has been continually receiving additions and repairs 
suited to the taste, fortune, or conveniency, of its successive proprietors." (Paley [1785] 2000, p. 328),

Successful institutions are more like patchworks of chance than ideal products of reason or nature. Joseph Cropsey claims indeed "there is nothing in the nature of things which will, or might 'inevitably', lead to the coming into being of the natural of the most expedient social arrangement." (1957, p. 73). The commercial state of society in Europe seems to have arrived by chance and through a non-predicted path, according to Smith: "But though this natural order of things must have taken place in some degree in every society, it has, in all modern states of Europe, been, in many respects, entirely inverted" (WN III.i.9, p. 380). Some economies for Smith started on the right path but then stalled, like the stationary state of the Chinese economy. The history of Bengal is regressive, not progressive. Bengal is in a declining state. Britain has progressed, but it is in serious danger of stalling or even regressing, if it falls prey to the attacks of mercantilism (WN I.viii.25-28). The whole Wealth of Nations may be read as a warning sign that the march of development may not be inevitable (Winch 1978, pp. 1-27, 164-188; Alvey 2003).

Social betterment thus differs from both micro-level improvements, macro-level utopias, and the various interpretations of stages of development. Smith describes different states of society in his Lectures on Jurisprudence (Smith [1762-3; 1766] 1978, LJA i.27, LJA iv.19-36) as well as in the first part of Book $\mathrm{V}$ of The Wealth of Nations. The stadial theory of development has been interpreted as a deterministic and inevitable march of development (e.g. Meek 1976, 1971). We started as hunter-gatherer societies to eventually develop into a pastoral stage, and agricultural stage, and finally into a commercial stage. The stadial theory of development has also been interpreted as a pedagogical taxonomy to explain different social, political, and economic institutions (Berry 2013; Paganelli Forthcoming). In one interpretation, human agency takes the back seat and material conditions are the primary sources of change. In the other interpretation, change is not necessarily explained, as what matters is the appropriateness of different institutions to specific circumstances. The idea of social betterment still maintains human agency, even if in a non-deterministic way. 


\section{Unintended Betterment: The silent revolution of commerce}

For Adam Smith, institutions are not and cannot be perfect. They do not even need to be. He tells us this in The Wealth of Nations ([1776] 1981), criticizing the Physiocrats who instead insist in demanding perfection. Human beings and human institutions are comfortably functioning even if they are not perfect (WN, IV.ix.28, pp. 673-674).

As Smith explains in The Wealth of Nations, rational and well-intentioned plans for social betterment are not only going to fail, they are actually going to make us worst off (WN IV.ii.9-10, p. 456). In his The Theory of Moral Sentiments ([1759] 1982), he describes a "man of system," so enamored with his beautiful ideal plan, that he forgets that real people are not as he dreams. The consequence of his attempt to implement his "wise" system will cause misery and social disorder (TMS VI.ii.2.17, pp. 233-234). Similarly, Hume claims that, given our inability to achieve an ideal of moral perfection, we need vices to compensate other vices, just "as one poison may be an antidote to another" (Hume [1752] 1985, p. 279). We are better off accepting human beings for what they are, with their functioning, even if imperfect, combination of vices and virtues. Attempts to change human nature and institutions to make them closer to some unrealistic ideals are going to make us worst off (Hume [1752] 1985, pp. 279-280).

But the rejection of the ideal plans of men of system does not necessarily imply political inaction. Active policies can and should be prescribed, but they should avoid creating utopian illusions that may cause social disasters (Farrant and Paganelli 2005). Imposing institutions on societies that have not evolved into them is a receipt for disaster. To impose a commercial order in a nomadic society, for example, would be not just ridiculous but dreadful (Millar [1779] 2006) since the chess pieces would move in disaccord from the planned design, to refer back to the image of the great chess board of society that Adam Smith uses (TMS VI.ii.2.17, pp. 233-234).

Smith often welcomes reforms, and supports a "science of the legislator." But a reformer is not necessarily a "man of system." A reformer, even an "improver", is someone who tries to understand the reality of things and does not try to change it in ways that are not "natural." A reformer, an "improver", unlike a "man of system", does take into consideration that the pieces on the human chessboard have a will of their own and does not 
try to move them in ways that are contrary to that will. He would consider that there are "formidable" powers of merchants and manufacturers which can "intimidate the legislature" (WN IV.ii.43, p. 471) so much that " $[t]$ o expect, indeed, that the freedom of trade should ever be entirely restored in Great Britain, is as absurd as to expect that an Oceana or Utopia should ever be established in it. Not only the prejudices of the publick, but what is much more unconquerable, the private interests of many individuals, irresistibly oppose it" (WN IV.ii.43, p. 471). Similarly, for Smith, those same real "formidable" interests and prejudices described in Book IV make the system of taxation that Smith envisions, should there be a union between Britain and its colonies, "a speculation [that] can at worst be regarded as a new Utopia, less amusing certainly, but not more useless and chimerical than the old one" (WN V.iii.68, p. 934).

The rejection of the ideal plans of men of system also does not necessarily imply that social betterment is impossible. For Smith, social betterment is possible, even if it is not the result of human design. Smith, like Hume, sees the possibility of social betterment in the accidental channeling of our vices, as well as of our virtues, into institutions that favor economic growth. It is the combination of our different passions that can, unintentionally, generate good outcomes for society. So, for example, as Smith writes in Book III of The Wealth of Nations, the fall of the oppressive system of feudal lords and the emergence of the system of natural liberty seem to be linked to the unintended consequences of our voraciousness:

All for ourselves, and nothing for other people, seems, in every age of the world, to have been the vile maxim of the master of mankind. As soon, therefore, as [the great barons] could find a method of consuming the whole value of their rents themselves, they had no disposition to share them with any other persons (WN III.iv.10, p. 418. See also WN V.i.g. 25, p. 803).

Which means that "most childish, the meanest and the most sordid of all vanities" which hopelessly attract them to the glitter of a "pair of diamond buckles perhaps, or [...] something as frivolous and useless" (WN III.iv.10, pp. 418-419) induced the great feudal lords to "gradually bartered their whole power and authority" (WN III.iv.10, pp. 418-419) and eventually sell their birthright and their estate. According to Smith, therefore, the accidental combination of the "folly" of gratifying "the most childish vanity" and the cupidity of merchants seeking to "turn[...] a penny wherever a penny was to be got" (WN III.iv.17, p. 422) brings down the feudal system 
and allows for the growth of the system of commerce and liberty which helps to sustain an increasing number of people. No government, no rational plan, no army, no virtue, no moral perfection improved human conditions in this case. For Smith, it is despite (or maybe even through) moral imperfection that mankind stumbles into social betterment.

As Smith writes in The Wealth of Nations, the silent revolution of commerce brings about "order and good government, and with them, the liberty and security of individuals [...]. This, though it has been the least observed, is by far the most important of all their effect" (WN III.iv.4, p. 412), as Hume before Smith recognizes (see also Rosenberg 1990). This social betterment includes functioning systems of justice which proved indispensable for growth and prosperity (Young 1997). It is not an ideal, but, rather a messy combination of real forces emerging from the slow revolution of commerce, which dismantles the feudal order and allows for social betterment. The silent and unplanned revolution of commerce achieves what no army, ideal system, or public governance would be able to achieve (e.g. WN III.iv.10, p. 418 and V.i.g. 24-25, p. 803).

Just as social betterment comes unintentionally from commerce, so it is not an ideal design but, rather, our propensity to truck, barter, and exchange that unintentionally brings about the division of labor that allows for commence:

This division of labour, from which so many advantages are derived, is not originally the effect of any human wisdom, which foresees and intends that general opulence to which it gives occasion. It is the necessary, though very slow and gradual consequence of a certain propensity in human nature which has in view no such extensive utility; the propensity to truck, barter, and exchange one thing for another (WN I.ii.1, p. 25. Emphasis added).

Note that while opulence is not a necessary result, when it does occur it is the necessary unintended consequence of this propensity to truck, barter, and exchange.

Adam Ferguson ([1767] 1995), even if more skeptical on the benefits of commerce than Smith or Hume, coined the phrase which is usually taken as the one-sentence description of the Scottish enlightenment as it captures its spirit: functioning institutions are "the results of human action, but not the execution of any human design" (p. 119). The real chessboard of human society generates institutions, thanks to the interaction of people, which allows for the betterment of society. This betterment is not inevitable and deterministic. But this betterment, if it does happen, can be 
seen through the increase in the rate of population growth and what today we call standards of living and life expectancy.

\section{Social betterment is measurable}

For Smith, improvements and social betterment can be measured by counting the increase or decrease of the number of adult people alive (WN I.viii). Judging social betterment by the rate of growth of society's population can be seen as a rejection of utopian standards. The increasing capability of a society to support life is just a tool of analysis, a practical measure of success. Focusing on population growth, Adam Smith does not mean seeing a specific population level as a target, but rather seeing the overall growth in population as an unintended consequence of improved living conditions. Increasing population is not an ideal aim, but a proxy that captures the improved ability of a society to provide better life expectancy through its improvement in the standards of living, and higher wages, especially for the working poor (WN I.viii.23, pp. 87-88).

Society's ability to support a growing number of individuals would eventually be embraced by evolutionary theorists. The fittest survive, as it was said after Adam Smith. So, the 'better' societies are the ones where population grows. I used 'better' in scare quotes because if one measures social betterment via population growth, one may run into problems. 'Better' has a normative component which natural evolutionists do not necessarily include. What survives and grows is not what is 'better' but simply what survives and grows (Hayek 2013). It is only when we believe that life is 'better' by some other standards that we can say that societies able to support more individuals are better. But, it is only in recent decades that scholars have been willing to separate the idea of normative progress from the idea of evolution and growth. Scottish thinkers were not necessarily willing to make that step for human population. More life is indeed better. Societies better able to support life are better societies than ones unable to support life (Paganelli 2013, 2017). Furthermore, for Smith, societies with an increasing population are the happiest (WN I.viii.43, p. 99).

The question can morph into a debate on what kind of society is better. Robert Wallace ([1753] 1969), for example, claims that ancient societies were better, and thus more populous, than modern ones. David Hume 
([1752] 1985), in his "Populousness of Ancient Nations," argues instead populations of antiquity are overestimated. Modern commercial societies are in fact more populous, and better, societies (on the Wallace-Hume debate see, e.g., Stangeland [1904] 1966). Adam Smith, following Hume, in his introduction to The Wealth of Nations, tells us that in non-commercial society, poverty is such that it forces people to abandon their children, elderly, and sick to die by exposure to the elements or "to be devoured by wild beast" (WN introduction 4, p. 10). Later in the book he tells us, again following Hume, that "The poverty of the lower ranks of people in China far surpasses that of the most beggarly nations in Europe. [...] In all great towns several [children] are every night exposed in the street, or drowned like puppies" (WN I.viii.24, pp. 89-90). Pre-commercial poverty forces parents to kill their children. The wealth that commerce brings about lets children live.

Population growth is thus for Smith an indication of betterment, not something rationally planned-marking him out from other thinkers of the time (Spengler [1942] 1980). Adam Ferguson makes the point, which Smith does not explicitly make, but that one could imagine he could have most likely not disagreed with: "the statesman who by premiums to marriage, by allurements to foreigners or by confining the natives at home apprehends that he has made the numbers of his people to grow is often like the fly in the fable, who admired its success in turning wheels and in moving carriages: he has only accomplished what was already in motion; he has dashed with his oar to hasten the cataract; and waved with his fan to give speed to the winds." (Ferguson [1767] 1995, p. 137).

Adam Smith brings the analysis a step forward though: it is not just the total number of people that matters, it is the rate of growth of population. He links social betterment with the ability to sustain a growing population. Smith's description of whether an economy is growing, sedentary, or declining, is linked with a growing, stable, or declining population. Growing economies support life, declining economies hinder life: "The most decisive mark of the prosperity of any country is the increase of the number of its inhabitants" (WN I.viii.23, pp. 87-88). North American colonies are not very populous, but they are growing, and have growing opportunities for social advancement. Population doubles every twenty-five years (WN I.viii.23, p. 88). People are industrious, have the opportunities to fulfill themselves, to marry young and have many healthy children who grow up to adulthood. Wages are high. "The greatest body of the people 
seems to be the happiest and the most comfortable" (WN I.viii.43, p. 99). We know it because:

\begin{abstract}
a young widow with four or five young children, who, among the middling or inferior ranks of people in Europe, would have so little chance for a second husband, is there [in North America] frequently courted as a sort of fortune. The value of children is the greatest of all encouragements to marriage. [...] [T] here is a continual complaint of the scarcity of hands in North America. The demand for labourers, the funds destined for maintaining them, increase, it seems, still faster than they can find labourers to employ (WN I.viii.23, p. 88).
\end{abstract}

China is rich and populous, but its economy is stationary. Its population is stationary too. People have lost their entrepreneurial spirit and enthusiasm. Wages are at subsistence. They marry and have children, just to "drown them like puppies" as mentioned above. The population is "dull", not "cheerful" (WN I.viii.43, p. 99).

In Bengal, on the other hand, the economy is declining and opportunities for social betterment seem non-existent. Wages here are below subsistence. People are "miserable" and "melancholic" (WN I.viii.43, p. 99):

many would not be able to find employment even upon . . hard terms, but would either starve, or be driven to seek subsistence either by begging, or by the perpetration perhaps of the greatest enormities. Want, famine, and mortality would immediately prevail ... till the number of inhabitants in the country was reduced to what could easily be maintained by the revenue and stock which remained in it, and which had escaped either the tyranny or calamity which had destroyed the rest. In [that] fertile country [of Bengal] which had before been much depopulated, three or four hundred thousand people die of hunger in one year (WN I.viii.26, p. 91).

Britain, according to Smith, falls in between the North American colonies and China. Its economy is growing, but not as much as North America's, even if more than China's; and indeed its population is also growing, less than America but more than China. Britain's population is expected to double every five hundred years, as opposed to the every twenty-five years in the colonies and as opposed to the flat growth of China (WN I.viii.23, p. 87-88).

Note that Smith does not address some of the problems that later scholars, such as David Ricardo or Thomas Robert Malthus, see in an increasing population. For Smith, there is no risk of a glut of lower income workers, or of over-population problems. Smith claims that "the demand for men, like that for any other commodity, necessarily regulates the production of men" (WN I.viii.40, p. 98): population increases only in a growing economy where there is a high demand for labor, which causes wages to 
increase and thus the ability to raise a numerous family. He does not even foresee the future problem of very wealthy societies today, where population tends to decrease, if not compensated for with migrants. He does note, though, that individual wealthy women have a significantly lower fertility rate than women of lower income (WN I.viii.37, p. 96-97).

Ferdinando Meacci (Forthcoming), though, notes that Smith does take for granted that the rate of growth of the long-run supply of labor (population, that is) must increase a lower rate than the long-run demand of it. This is implicitly corroborated in a different context by Reinhard Schumacher (2016). For Schumacher, indeed, Smith does not take part in the socalled rich country-poor country debate because, in this account, Smith predicts a convergence of poor countries to rich counties, which would make all better off, even if all would reach a stationary state.

In Schumacher's account, the debate instead saw a split between David Hume and Henry Home, Lord Kames on the one hand and Josiah Tucker and James Oswald on the other. Hume and Kames saw convergence, Tucker and Oswald an increasing divergence. But the convergence Hume and Kames saw implies a decay of the rich countries, as a consequence of their higher wages, which would induce outsourcing to poor and cheaper countries. The high wages of rich countries, for Tucker and Oswald, are instead the cause of their critical and permanent advantage over poor countries, as they induce immigration of skilled workers. For Smith instead, high wages are simply a sign of economic growth, incentivizing the "production of men."

While I do not agree with Schumacher's conclusions that "Smith envisions a limit to economic growth and progress" (p. 777) and that the natural progress of opulence is inevitable, I do agree with him in his criticism of Istvan Hont (1983) that the Wealth of Nations shows significant changes from the Lectures on Jurisprudence (p. 787). While Schumacher focuses on the role of capital in the Wealth of Nations and its absence in the Lectures, what is relevant for me is Smith's treatment of population. In the Lectures, population seemed to grow with the availability of means of subsistence, and when there is enough pressure on them, there would be incentives to find better means of subsistence (LJA iv 19-36). Population growth seemed to be the cause of economic growth. In the Wealth of Nations, this position is abandoned. Population growth becomes here a consequence of economic growth, as demonstrated above, and not a cause of it. 
Another point worth noting is that this increase in the means of supporting a growing population is not a consequence of, or anyway linked to, individual moral improvement (on some moral challenges and solutions in the population debate see Levy 1999). The overall system of morals may become better, in the sense, for example, that the wealth of a commercial society allows us to see and avoid the "so dreadful a violation of humanity" and "the most unjust and unreasonable conduct" (TMS V.2.15, pp. 209-210) of some practices, such as infanticide, which are commonly accepted and in poor non-commercial societies and "undoubtedly more pardonable than in any other" societies (TMS V.2.15, pp., 209-210). Similarly, the wealth of commercial societies is a fertile ground for the development of a set of virtues linked to humanity. But it is not the individual moral improvement that creates a better society. It is the "tranquility" and the opulence that commerce brings about that may offer the opportunities for human beings to flourish (TMS III.3.37, p. 153). For Smith, individuals are imperfect and it is not feasible for them to shed their imperfections. It is not that perfection is unwelcome: it is that perfection is not feasible. Within themselves, individuals have a mix of social and selfish sentiments, of virtues and vices, of passions and reason. Adam Smith criticizes his "never to be forgotten" teacher, Francis Hutchison, because he relies excessively on benevolence, which is unrealistic (TMS VII.ii.3). He also criticizes Bernard Mandeville, because he relies excessively on selfishness, which is also unrealistic (TMS VII.ii.4). David Hume criticizes those who aspire to a better society by eliminating vices, because a perfectly virtuous person is not a feasible possibility ([1752] 1985, p. 363).

\section{Conclusion}

Adam Smith believes that commerce brings about social betterment. Yet, he does not seem to believe that the achievement of a commercial society is or should be a planned action meant to reach a perfect ideal state or an inevitable step from previous stages of development. Social betterment in Smith is present but it is not utopic. It is achieved by micro rational improvements due to our better understanding of the real world and the acceptance of our limitations, and by accidental evolution at the macro social level. His focus on micro-improvements should be seen as limited 
to the local level. His focus on macro-level betterment is instead limited to the measurement of real changes in population.

\section{References}

ALVEY, J. E. 'Adam Smith's View of History: Consistent or Paradoxical?', History of the Human Sciences, 16: 1-25, 2003.

BERLIN, I. The Crooked Timber of Humanity. Fontana Press: London, 1991.

BERRY, C. J. Social Theory of the Scottish Enlightenment. Edinburgh Univ. Press: Edinburgh, 1997.

BERRY, C. J. The idea of commercial society in the Scottish enlightenment. Edinburgh University Press: Edinburgh, Scotland, 2013.

BONNYMAN, B. The Third Duke of Buccleauch and Adam Smith: Estate Management and Improvement in Enlightenment Scotland. Edinburgh University Press: Edinburgh, 2014.

CLAEYS, G. Utopias of the British enlightenment. Cambridge University Press: Cambridge [England]; New York, NY, 1994.

CROPSEY, J. Polity and Economics: an interpretation of the principles of Adam Smith. St. Augustine's Press: South Bend, Indiana, 1957.

DAVIS, J. C. 'Going Nowhere: Travelling to, through, and from Utopia', Utopian Studies, 19: $1-23,2008$.

DIMAND, R. W. 'David Hume and Irving Fisher on the Quantity Theory of Money in the Long Run and the Short Run', European Journal of the History of Economic Thought, 20: 284304, 2013.

FARRANT, A.; PAGANELLI, M. P. 'Are Two Knaves Better Than One? Hume, Buchanan, and Musgrave on Economics and Government', History of Political Economy, 37: 71-90, 2005.

FERGUSON, A. An essay on the history of civil society / Adam Ferguson; edited by Fania Oz-Salzberger. Cambridge ; New York : Cambridge University Press, [1767] 1995.

FEST, J. Il Sogno Distrutto: La Fine dell'Età delle Utopie. Garzanti: Milano, 1992.

GARDINER, M. 'Utopia and Everyday Life in French Social Thought', Utopian Studies, 6: 90-123, 1995.

HAYEK, F. A. 'The Overrated Reason', Journal of the History of Economic Thought, 35: 239-56, 2013.

HONT, I. 'The "rich countrypoor country" debate in Scottish classical political economy.' in Istvan and M. Ignatieff hont (ed.), Wealth and virtue: the shaping of political economy in the Scottish enlightenment. Cambridge University Press: Cambridge, 1983.

HOUSTON, C. 'Utopia, Dystopia or Anti-utopia? Gulliver's Travels and the Utopian Mode of Discourse', Utopian Studies, 18: 425-42, 2007.

HUME, D. Essays, moral, political, and literary. Liberty Fund: Indianapolis, [1752] 1985.

HUME, D. Hisotry of England. Liberty Fund: Indianapolis, [1762] 1985. 
JONSSON, F. A. Enlightenment's Frontier: the Scottish Highlands and the origins of Environmentalism. Yale University Press: New Haven and London, 2013.

LEVY, D. M. 'Malthusianism or Christianity: The Invisibility of Successful Radicalism', Historical Reflections / Réflexions Historiques, 25: 61-93, 1999.

LUKES, S.; URBINATI, N. Condercet: Political Writings. Cambridge University Press: New York, 2012.

MEACCI, F. The link between capital accumulation and increasing wages in an updated version of Adam Smith's theory of population, Journal of the History of Economic Thought, v. 42, i. 3, p. 385-400, 2020.

MEEK, R. L. 'Smith, Turgot, and the "Four Stages" Theory', History of Political Economy, 3: 9-27, 1971.

MEEK, R. L. Social science and the ignoble savage. Cambridge University Press: Cambridge; New York, 1976.

MILLAR, J. The origin of the distinction of ranks, or, An inquiry into the circumstances which give rise to influence and authority, in the different members of society / John Millar; edited and with an introduction by Aaron Garrett. Liberty Fund: Indianapolis, [1779] 2006.

PAGANELLI, M. P. 'Commercial Relations: From Adam Smith to Field Experiments.' in Christopher J. Berry, Maria Pia Paganelli and Craig Smith (eds.), The Oxford Handbook of Adam Smith, Oxford University Press: Oxford, New York, 2013..

PAGANELLI, M. P. 'David Hume on Banking and Hoarding', Southern Economic Journal, 80: 968-80, 2014.

PAGANELLI, M. P. '240 Years of Adam Smith's Wealth of Nations ', Nova Economia, 27: 7-19, 2017.

PAGANELLI, M. P. 'Adam Smith and Economic Development in Theory and Practice: a rejection of stadial model?', Journal of the History of Economic Thought, Forthcoming.

PALEY, W. The principles of moral and political philosophy. Liberty Fund: Indianapolis, Ind., [1785] 2000.

PHILLIPSON, N. Scotland in the Age of Improvement. Edinburgh University Press: Edinburgh, 1970.

POPPER, K. R. Conjectures and refutations: the growth of scientific knowledge. Routledge: London ; New York, 1989.

RADNER, J. B. 'The Fall and Decline: Gulliver's Travels and the Failure of Utopia', Utopian Studies, 3: 50-74, 1992.

ROSENBERG, N. 'Adam Smith and the Stock of Moral Capital', History of Political Economy, 22: 1-17, 1990.

SCHOFIELD, P.; HARRIS, J. Jeremy Bentham: Legislator of the World. Writings on Codification, Law, and Education. Oxford University Press: New York, 1999.

SCHUMACHER, R. 'Adam Smith and the "rich country-poor country" debate: eighteenthcentury views on economic progress and international trade', The European Journal of the History of Economic Thought, 23: 764-93, 2016.

SMITH, A. Lectures on Rhetoric and Belles Lettres. Liberty Fund, 1985. 
SMITH, A. The theory of moral sentiments. Liberty Classics: Indianapolis, [1759] 1982.

SMITH, A. Lectures on Jurisprudence. Liberty Fund: Indianapolis, [1762-3; 1766] 1978.

SMITH, A. An inquiry into the nature and causes of the wealth of nations. Liberty Classics: Indianapolis, [1776] 1981.

SMITH, C. '"Great reformation in the manners of mankind": Utopian thought in the Scottish Reformation and Enlightenment', Utopian Studies, 16, 2005.

SMITH, C. Adam Smith's political philosophy: the invisible hand and spontaneous order. Routlege: London, 2006.

SPENGLER, J. J. French predecessors of Malthus; a study in eighteenth-century wage and population theory. Octagon Books: New York, [1942] 1980.

STANGELAND, C. E. Pre-Malthusian doctrines of population; a study in the history of economic theory. A.M. Kelly: New York, [1904] 1966.

SWIFT, J. Gulliver's travels. Oxford University Press: Oxford ; New York, [1973] 2005.

WALLACE, R. A Dissertation on the Numbers of Mankind: In Ancient and Modern Times. A.M. Kelly: New York, [1753] 1969.

WINCH, D. Adam Smith's Politics: An Essay in Historiographic Revision. Cambridge University Press: Cambridge, 1978.

YOUNG, J. Economic as a Moral Science: The Political Economy of Adam Smith. Edward Elgar: Cheltenham, UK and Lyme, US, 1997.

\section{About the author}

Maria Pia Paganelli-mpaganel@trinity.edu

Department of Economics, Trinity University, San Antonio, TX, United States of America.

ORCID: https://orcid.org/0000-0002-5796-4519.

Thanks to Carlos Eduardo Suprinyak for encouraging me to work on this topic. Thanks also to Craig Smith, the participants of the 2014 Seminário de Diamantina, and of the 2018 seminar at the University of Tokyo for useful comments on earlier versions on this paper. A deep thanks to two anonymous referees. All mistakes are mine.

\section{About the article}

Submission received on May 25, 2020. Approved for publication on July 29, 2020. 